\title{
Front Matter: Volume 10987
}

, "Front Matter: Volume 10987," Proc. SPIE 10987, Algorithms for Synthetic Aperture Radar Imagery XXVI, 1098701 (18 July 2019); doi:

$10.1117 / 12.2537886$

SPIE Event: SPIE Defense + Commercial Sensing, 2019, Baltimore, MD, United SPIE. States 


\title{
PROCEEDINGS OF SPIE
}

\section{Algorithms for Synthetic Aperture Radar Imagery XXVI}

\author{
Edmund Zelnio \\ Frederick D. Garber \\ Editors
}

18 April 2019

Baltimore, Maryland, United States

Sponsored and Published by

SPIE 
The papers in this volume were part of the technical conference cited on the cover and title page. Papers were selected and subject to review by the editors and conference program committee. Some conference presentations may not be available for publication. Additional papers and presentation recordings may be available online in the SPIE Digital Library at SPIEDigitalLibrary.org.

The papers reflect the work and thoughts of the authors and are published herein as submitted. The publisher is not responsible for the validity of the information or for any outcomes resulting from reliance thereon.

Please use the following format to cite material from these proceedings:

Author(s), "Title of Paper," in Algorithms for Synthetic Aperture Radar Imagery XXVI, edited by Edmund Zelnio, Frederick D. Garber, Proceedings of SPIE Vol. 10987 (SPIE, Bellingham, WA, 2019) Seven-digit Article CID Number.

ISSN: 0277-786X

ISSN: 1996-756X (electronic)

ISBN: 9781510626393

ISBN: 9781510626409 (electronic)

Published by

SPIE

P.O. Box 10, Bellingham, Washington 98227-0010 USA

Telephone +1 3606763290 (Pacific Time) · Fax +1 3606471445

SPIE.org

Copyright @ 2019, Society of Photo-Optical Instrumentation Engineers.

Copying of material in this book for internal or personal use, or for the internal or personal use of specific clients, beyond the fair use provisions granted by the U.S. Copyright Law is authorized by SPIE subject to payment of copying fees. The Transactional Reporting Service base fee for this volume is $\$ 18.00$ per article (or portion thereof), which should be paid directly to the Copyright Clearance Center (CCC), 222 Rosewood Drive, Danvers, MA 01923. Payment may also be made electronically through CCC Online at copyright.com. Other copying for republication, resale, advertising or promotion, or any form of systematic or multiple reproduction of any material in this book is prohibited except with permission in writing from the publisher. The CCC fee code is 0277$786 \times / 19 / \$ 18.00$.

Printed in the United States of America by Curran Associates, Inc., under license from SPIE.

Publication of record for individual papers is online in the SPIE Digital Library.

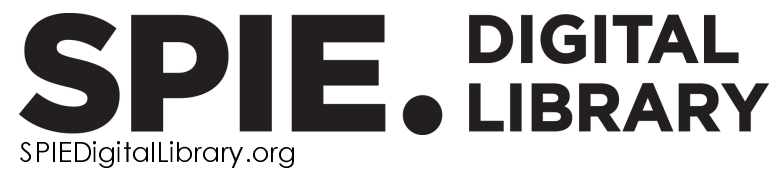

Paper Numbering: Proceedings of SPIE follow an e-First publication model. A unique citation identifier (CID) number is assigned to each article at the time of publication. Utilization of CIDs allows articles to be fully citable as soon as they are published online, and connects the same identifier to all online and print versions of the publication. SPIE uses a seven-digit CID article numbering system structured as follows:

- The first five digits correspond to the SPIE volume number.

- The last two digits indicate publication order within the volume using a Base 36 numbering system employing both numerals and letters. These two-number sets start with $00,01,02,03,04$, 05, 06, 07, 08, 09, OA, OB ... 0Z, followed by 10-1Z, 20-2Z, etc. The CID Number appears on each page of the manuscript. 


\title{
Contents
}

\author{
$\checkmark \quad$ Authors \\ vii Conference Committee
}

ADVANCED SENSOR TECHNOLOGIES

1098702 The 3D complex damped exponential Cramer-Rao estimation bound and algorithms [10987-1]

1098703 Effects of region of interest selection on phase history based SAR moving target autofocus [10987-2]

1098707 Multi-sensor synthetic data generation to performance characterization [10987-7]

SYNTHETIC APERTURE RADAR TARGET RECOGNITION

10987 OC Realistic SAR data augmentation using machine learning techniques [10987-12]

10987 OG A deep learning approach to the Synthetic and Measured Paired and Labeled Experiment (SAMPLE) challenge problem [10987-16]

$10987 \mathrm{OH} \quad$ A SAR dataset for ATR development: the Synthetic and Measured Paired Labeled Experiment (SAMPLE) [10987-17]

10987 Ol Synthetic data accuracy sensitivity to CAD model accuracy using ATR-based metrics [10987-18]

10987 OK A performance modeling framework for large scale synthetically derived performance estimates [10987-20]

10987 OL Articulation study for SAR ATR baseline algorithm [10987-21] 
Proc. of SPIE Vol. 10987 1098701-4

Downloaded From: https://www.spiedigitallibrary.org/conference-proceedings-of-spie on 26 Apr 2023 Terms of Use: https://www.spiedigitallibrary.org/terms-of-use 


\section{Authors}

Numbers in the index correspond to the last two digits of the seven-digit citation identifier (CID) article numbering system used in Proceedings of SPIE. The first five digits reflect the volume number. Base 36 numbering is employed for the last two digits and indicates the order of articles within the volume. Numbers start with 00, 01, 02, 03, 04, 05, 06, 07, 08, 09, OA, OB...0Z, followed by 10-12, 20-2Z, etc.

Branch, Eric, $\mathrm{Ol}$

DeGuchy, Omar, 0C

Garren, David A., 03

Goley, G. Steven, OK, OL

Kaminski, John, OC

Levy, Michael, ol

Lewis, Benjamin, OC, OG, OH

Nehrbass, John W., OH, Ol

Nehrbass, Stephen, OL

Nolan, Adam R., 07, OK, OL

Paulson, Christopher R., 07, OL

Pepin, Matthew, 02

Rosencrantz, Stephen, $\mathrm{OH}$

Scarnati, Theresa, $0 \mathrm{G}, \mathrm{OH}$

Sebastian, Joseph, OC

Sudkamp, Elizabeth R., $\mathrm{OH}, \mathrm{Ol}$

Thelen, Brian, OK

Westerkamp, Lori, 07

Xique, Ismael, OK

Zelnio, Edmund, 07, OH, OL 
Proc. of SPIE Vol. 10987 1098701-6

Downloaded From: https://www.spiedigitallibrary.org/conference-proceedings-of-spie on 26 Apr 2023 Terms of Use: https://www.spiedigitallibrary.org/terms-of-use 


\title{
Conference Committee
}

\author{
Symposium Chairs \\ Jay Kumler, JENOPTIK Optical Systems, LLC (United States) \\ Ruth Moser, Air Force Research Laboratory (United States) \\ Symposium Co-chair \\ John Pellegrino, Electro-Optical Systems Laboratory, Georgia Institute \\ of Technology (United States) \\ Conference Chairs \\ Edmund Zelnio, Air Force Research Laboratory (United States) \\ Frederick D. Garber, Wright State University (United States) \\ Conference Program Committee \\ Joshua N. Ash, Wright State University (United States) \\ David Blacknell, Defence Science and Technology Laboratory \\ (United Kingdom) \\ Mujdat Cetin, Sabanci University (Turkey) \\ Gil J. Ettinger, Systems \& Technology Research (United States) \\ David A. Garren, Naval Postgraduate School (United States) \\ Eric R. Keydel, Leidos, Inc. (United States) \\ Juan Li, University of Central Florida (United States) \\ Uttam Kumar Majumder, Air Force Research Laboratory \\ (United States) \\ Michael J. Minardi, Air Force Research Laboratory (United States) \\ Randolph L. Moses, The Ohio State University (United States) \\ Les Novak, Scientific Systems Company, Inc. (United States) \\ Christopher R. Paulson, Air Force Research Laboratory (United States) \\ Lee C. Potter, The Ohio State University (United States) \\ Brian Rigling, Wright State University (United States) \\ Timothy D. Ross, Jacobs Technology (United States)
}

\section{Session Chairs}

1 Advanced Sensor Technologies

Christopher R. Paulson, Air Force Research Laboratory (United States)

2 Synthetic Aperture Radar Target Recognition

Uttam Kumar Majumder, Air Force Research Laboratory

(United States) 
Proc. of SPIE Vol. 10987 1098701-8

Downloaded From: https://www.spiedigitallibrary.org/conference-proceedings-of-spie on 26 Apr 2023 Terms of Use: https://www.spiedigitallibrary.org/terms-of-use 